\title{
A MORPHO-SYNTACTIC ERROR ANALYSIS OF STUDENTS' WRITING AT THE STATE MADRASAH TSANAWIYAH OF SUKOHARJO
}

\author{
Bayu Nandra Ramadhan ${ }^{a}$ \\ Sebelas Maret University, bayunandraramadhan@gmail.com \\ Endang Fauziati ${ }^{b}$ \\ Sebelas Maret University, endang.fauziati@gmail.com \\ Suparnoc $^{c}$ \\ Sebelas Maret University,
}

\begin{abstract}
English is considered as an Indonesian students' foreign language which is not used frequently in their daily conversations. Since writing in English is a challenging experience for Indonesian students, they sometimes commit errors in grammar and sentence structures. Learners' errors were considered as the best sources to identify students' writing skills deficiency. They can be useful for teachers, learners, textbook providers, education system and so on. This descriptive qualitative research investigated the Indonesian EFL linguistics taxonomy of morpho-syntactic errors and the sources of the errors. The participants of the study were the third graders of the State Madrasah Tsanawiyah Sukoharjo. They were asked to write a descriptive text about their mother. After collecting the data and categorizing and identifying the erroneous areas in their work, the data were analysed using the linguistic taxonomy of errorscoined by Keshavarz (2006). The results of this study showed that the most frequent part of the students' errors based on morpho-syntactical errors was "errors due to a lack of concord" and the minimum frequency was found to be "wrong word order". Then, the most common error viewed from the sources of the errors was overgeneralization error, and the minimum frequency was related to "faulty categorization".
\end{abstract}

Keywords: EFL learners; error analysis; linguistic taxonomy; morphosyntactic errors. 
Ramadhan et al., A Morpho-Syntactic Error...

\section{INTRODUCTION}

Indonesian people are not the native of English. It means that their mother tongue is not English. There are Javanese people who usetheir local language (Javanese language) as their first language. English language becomes even the third language used by them after Indonesian language. Since Indonesian English learners are not the native of English, they find it difficult to develop their English skills. One of the English skills is writing. In school, students are usually asked to write an essay or text using English. In this case, students commonly transfer their native language into the target language (English). Itis evidentthat many errors often occur during the process of their writing. Some aspects of English such as grammar, vocabulary, spelling, as well as punctuation still become a task for them to master. In other words, those aspects are worth their attention as a central power to be successful in writing English.

In a study of investigating students' errors, there are two terms that should be understood in order to avoid misconception. It should be clear to distinguish between the term mistake and error asthose terms are completely different in use that should be clearly identified. An error arises only when there was no intention to commit one (James, 1998 as cited in Fauziati, 2016). According to Fauziati (2016) errors are systematic, consistent deviance which is characteristic of the learner's linguistic system at a given stage of learning. On the other side, mistakes are deviations due to performance factors such as memory limitation, fatigue, and emotional strain (Fauziati, 2016). When making a mistake, the learner can correct it by himself by giving more attention toward the mistake. However, the errors made by the learners cannot be corrected by themselves without the aids of the others.

The context that has been used in this research is the context of junior high school in Sukoharjo. The subjects of the research are the students of MTs N Sukoharjo. MTs N Sukoharjo is the one and only Islamic state based junior high school in Sukoharjo sub-district. In this school, there is a special program that has been called Program Khusus. This program is intended to the 
students who will get more intensive program rather than the regular one. The term 'special program' will be used to refer Program Khusus. The subjects of this research are the third-grade students of special program of MTs N Sukoharjo. The students should join an English Conversation class which is compulsory for them. Although they are the chosen ones and they are provided with an English conversation class, they still make enormous errors in writing an English essay. It will be an interesting study if we investigate the errors made by the students of special program in the one and only Islamic based junior high school in Sukoharjo sub-district.

Error Analysis is an attempt to analyse the errors learners make in relation to the target language (Corder, 1971) in (Hariri, 2012: 4856). Error analysis has made a significant contribution to the theoretical consciousness-raising of applied linguists and language practitioners (Amin, 2017). The purpose of error analysis is to find what the learners knows and what does not know and to ultimately enable the teacher to supply him not just with the information that his hypothesis is wrong, but also, importantly with the right sort of information or data for him to form a more adequate concept of rule in the target language (Corder, 1974) in (Fauziati, 2016: 105). According to Fauziati (2016: 105) the goal of error analysis to find out the psycholinguistics process or cognitive mechanism of second language learning. Vahdatinejad (2008) in (Zawahreh, 2012: 282) mentioned that error analyses are fruitful in determining what a learner needs to be taught because it provides the necessary information about what is lacking in the linguistic competence. There are many types of taxonomy in categorizing the errors. Those are surface strategy taxonomy, comparative taxonomy, communicative effect taxonomy, and morpho-syntactic taxonomy. The taxonomy that has been used in this research is morpho-syntactic taxonomy. Morpho-syntactic error taxonomy is the taxonomy based on the misapplication of morphological inflection and syntactic rules (Vosse, 1992: 111).

The studies of the errors that used morpho-syntactic taxonomy have been conducted in some countries. Two of them are the research of Hariri and the research of Vosse. Hariri's 
research entitled Taxonomy of Morpho-Syntactic Errors and Error Analysis focused on the use of morpho-syntactic taxonomy to categorize the errors made by the students in Iran context. Moreover, he also used a theory to categorize the source of errors. The result of his study is that the Iranian students make errors majorly in the use of preposition and the source of errors majorly comes from intralingual errors. Then, the second research by Vosseentitled Detecting and Correcting Morpho-syntactic Errors in Real Texts focused on the categorization of errors based on the morphosyntactic taxonomy in Dutch context. Those two researches use the morpho-syntactic taxonomy to categorize the errors made by the students. This research also uses morpho-syntactic theory to categorize the students' errors. While the research by Hariri uses Iranian context and the research by Vosse uses Dutch context, this research uses Indonesian context of the research.

Based on the reasons that have been elaborated before, the researchers conducted a research entitled "a morpho-syntactic error analysis of students' writing at the state Madrasah Tsanawiyah of Sukoharjo. This research aims to reveal the type of errors made by the students of third grade in MTs N Sukoharjo and to unveil the source of errors that have been made by them. By using the result of this research, the teacher can identify what kind of errors that have been made by his/ her students, so that, he/ she can focus on fixing the errors to make the students better in writing an English essay.

\section{METHOD}

In this study, the researchers use descriptive qualitative research to describe the type, the frequency, and the sources of errors in written production made by third grade students of State Madrasah Tsanawiyah of Sukoharjo. As stated by Kothari (2004: 37), descriptive research studies are those studies which are concerned with describing the characteristics of a particular individual or of a group. The data were gathered from written productions of descriptive text of five students of State Madrasah Tsanawiyah of Sukoharjo. All the writings have the same topic 
about the description of the students' mother. After the data were gathered, they were read carefully and the erroneous parts were identified. Finally, they were categorized and analysed based on linguistic taxonomy of errors proposed by Keshavarz (2006) which includes the classifications of morpho-syntactical errors and sources of the errors.

\section{Findings}

The Table 1 shows the items in linguistic taxonomy and their description. An example of the learners' errors is presented and the erroneous sentences are distinguished by the sign of "*" from its correct form.

\section{Table 1.}

\begin{tabular}{|c|c|c|}
\hline $\begin{array}{l}\text { Linguistic } \\
\text { taxonomy }\end{array}$ & $\begin{array}{l}\text { Descripti } \\
\text { on }\end{array}$ & Evidence \\
\hline $\begin{array}{l}\text { Errors in the } \\
\text { use of articles }\end{array}$ & $\begin{array}{l}\text { Inappropria } \\
\text { te use of } \\
\text { article 'the' }\end{array}$ & $\begin{array}{l}\text { I always pray to the god for to be } \\
\text { the good boy.* } \\
\text { (I always pray to the God to be } \\
\text { a good boy) }\end{array}$ \\
\hline $\begin{array}{l}\text { Errors in the } \\
\text { use of } \\
\text { prepositions }\end{array}$ & $\begin{array}{l}\text { Redundant } \\
\text { use of } \\
\text { preposition }\end{array}$ & $\begin{array}{c}\text { I always pray to the god for to be } \\
\text { the good boy.* } \\
\text { (I always pray to the God to } \\
\text { be a good boy) }\end{array}$ \\
\hline $\begin{array}{l}\text { Wrong word } \\
\text { order }\end{array}$ & $\begin{array}{c}\text { wrong } \\
\text { position of } \\
\text { adverb } \\
\text { "sometime } \\
\text { s" }\end{array}$ & $\begin{array}{l}\text { My mom sometimes is mad } \\
\text { with me because I nanghty.* } \\
\text { (My mom is sometimes mad } \\
\text { with me because I am naughty) }\end{array}$ \\
\hline $\begin{array}{l}\text { Errors due to } \\
\text { lack of concord }\end{array}$ & $\begin{array}{l}\text { Lack of } \\
\text { subject-verb } \\
\text { agreement }\end{array}$ & $\begin{array}{c}\text { She always wake me up in the } \\
\text { morning* } \\
\text { (She always wakes me up in } \\
\text { the morning) }\end{array}$ \\
\hline $\begin{array}{l}\text { Wrong use of } \\
\text { conditional } \\
\text { sentences }\end{array}$ & $\begin{array}{l}\text { Errors in } \\
\text { the use of } \\
\text { conditional } \\
\text { sentences }\end{array}$ & $\begin{array}{l}\text { I so sad, if she not together me.* } \\
\text { (I will be so sad, if she does } \\
\text { not get together with me) }\end{array}$ \\
\hline Wrong use of & - & - \\
\hline
\end{tabular}


Ramadhan et al., A Morpho-Syntactic Error...

\begin{tabular}{|c|c|c|}
\hline tenses & & \\
\hline $\begin{array}{l}\text { Wrong use of } \\
\text { adverb }\end{array}$ & $\begin{array}{c}\text { Error in the } \\
\text { use of } \\
\text { adverb }\end{array}$ & $\begin{array}{c}\text { Everyday morning I belp my } \\
\text { mother because I love my mom } \\
\text { everyday* } \\
\text { (Every morning I help my } \\
\text { mother because I love my } \\
\text { mom everyday) }\end{array}$ \\
\hline $\begin{array}{l}\text { Wrong use of } \\
\text { verb group }\end{array}$ & $\begin{array}{l}\text { Error in the } \\
\text { use of verb } \\
\text { and adverb }\end{array}$ & $\begin{array}{l}\text { She hard worker for me* } \\
\text { (She works hard for me) }\end{array}$ \\
\hline $\begin{array}{c}\text { Errors in the } \\
\text { use of relative } \\
\text { clauses } \\
\text { and relative } \\
\text { pronouns }\end{array}$ & $\begin{array}{l}\text { Omission of } \\
\text { relative } \\
\text { pronoun } \\
\text { 'who' }\end{array}$ & $\begin{array}{c}\text { I have my parent is my father } \\
\text { and mother* } \\
\text { (I have parents who are my } \\
\text { father and mother) }\end{array}$ \\
\hline
\end{tabular}

Table 2: Frequency of the Morpho-Syntactical Errors

\begin{tabular}{llcc} 
No. & Morpho-syntactical errors & $\begin{array}{c}\text { No. of } \\
\text { errors }\end{array}$ & $\mathbf{( \% )}$ \\
\hline 1. & Errors in the use of articles & 2 & 3,9 \\
2. & Errors in the use of & 9 & 17,6 \\
& prepositions & 2 & 3,9 \\
3. & Wrong word order & 20 & 39,2 \\
4. & Errors due to lack of concord & 3 & 5,9 \\
5. & Wrong use of conditional & & \\
& sentences & 0 & 0 \\
6. & Wrong use of tenses & 4 & 7,8 \\
7. & Wrong use of adverb & 8 & 15,7 \\
8. & Wrong use of verb group & 3 & 5,9 \\
9. & Errors in the use of relative & & \\
& clauses & & \\
& and relative pronouns & Total of Errors & 51 \\
\hline
\end{tabular}

Sources of errors: After classifying the errors according to morpho-syntactic taxonomy, the researchers classify the errors to their sources. Table 3 shows the classification of the sources of the 
errors that contains the categories, the examples, the correction, and the number of errors for each. Figure 3 is a pie chart which also shows the sources of errors.

According to Corder (1967) the learner's errors have different significance, those are:

1) L2 acquisition should not be looked at from a purely pedagogical perspective.

2) Errors in L2 are interesting because they reflect underlying linguistics rules.

3) The study of L2 can be seen as a subfield of general linguistics or cognitive science.

According to Keshavarz (2006) there is a classification of errors based on the sources. The classification is as follows:

1) Transfer of Morphological elements

2) Transfer of Grammatical elements

3) Transfer of Lexico-semantic elements

a) Cross-associational

b) False-cognates

4) Transfer of Stylistic and Cultural elements

a) Overgeneralization

b) Ignorance of rule restriction

c) Hyperextension

d) Hypercorrection

e) Faulty categorization

5) Language Learning Strategies
a) Simplification
b) Transfer of rules
6) Communication strategies
a) Prefabricate pattern
b) Language switch
c) Appeal to authority
d) Avoidance strategy
e) Topic avoidance
f) Message abandonment

Table 3: Errors Sources

$\begin{array}{llll}\text { Source of Errors } & \text { Example } & \text { Correction } & \text { No }\end{array}$


Ramadhan et al., A Morpho-Syntactic Error...

\begin{tabular}{|c|c|c|c|}
\hline Overgeneralization & $\begin{array}{l}\text { At morning, my } \\
\text { mom wake me up } \\
\text { and ask me to pray }\end{array}$ & $\begin{array}{l}\text { At morning, } \\
\text { my mom } \\
\text { wakes me up } \\
\text { and asks me } \\
\text { to pray }\end{array}$ & 22 \\
\hline Hypercorrection & $\begin{array}{l}\text { I always pray to the } \\
\text { god for to be the } \\
\text { good boy }\end{array}$ & $\begin{array}{l}\text { I always pray } \\
\text { to the god to } \\
\text { be a good } \\
\text { boy }\end{array}$ & 10 \\
\hline $\begin{array}{l}\text { Faulty } \\
\text { categorization }\end{array}$ & $\begin{array}{l}\text { My mom education } \\
\text { for to be good boy }\end{array}$ & $\begin{array}{l}\text { My mom } \\
\text { educates me } \\
\text { to be a good } \\
\text { boy }\end{array}$ & 6 \\
\hline Simplification & $\begin{array}{l}\text { I so sad, if she not } \\
\text { together me. }\end{array}$ & $\begin{array}{l}\text { I will be so } \\
\text { sad if she } \\
\text { does not get } \\
\text { together } \\
\text { with me. }\end{array}$ & 9 \\
\hline Transfer of Rule & $\begin{array}{l}\text { I don't will angry } \\
\text { because mom }\end{array}$ & $\begin{array}{l}\text { I will not be } \\
\text { angry } \\
\text { because of } \\
\text { mom }\end{array}$ & 4 \\
\hline
\end{tabular}

Table 4: Observe Frequency of Sources of Errors

\begin{tabular}{lll}
\hline Source of Errors & No & $\mathbf{( \% )}$ \\
\hline Overgeneralization & 22 & 43.13 \\
\hline Hypercorrection & 10 & 19.6 \\
\hline Faulty categorization & 6 & 11.76 \\
\hline Simplification & 9 & 17.64 \\
\hline Transfer of Rule & 4 & 7.84 \\
\hline Total of Errors & $\mathbf{5 1}$ & \\
\hline
\end{tabular}




\section{Sources of Errors}

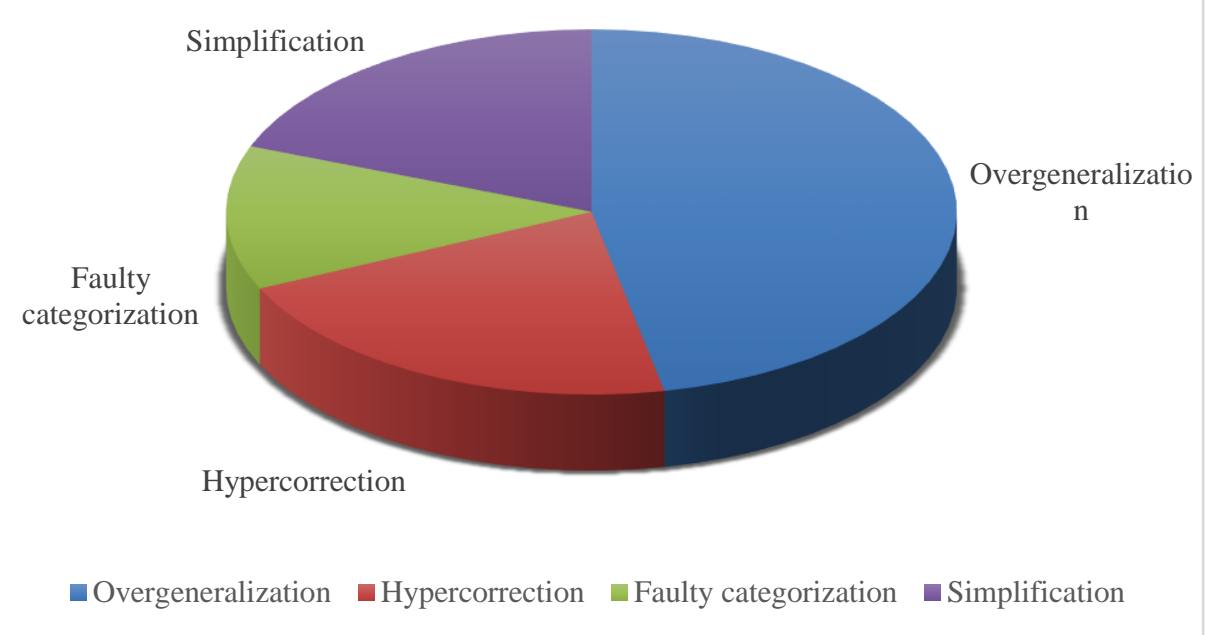

Fig. 1: Pie-chart of sources of errors

\section{DISCUSSION}

This part discusses about the findings of the research. Based on the data that has been analysed in the previous part, it is found that the students' errors are classified into two categories. Those are morpho-syntactical errors and sources of the errors. In the category of morpho-syntactical errors, the result reveals that there are eight types of errors committed by the students. Those are errors in the use of articles $(3,9 \%)$, errors in the use of prepositions $(17,6 \%)$, wrong word order $(3,9 \%)$, errors due to lack of concord $(39,2 \%)$, wrong use of conditional sentences $(5,9 \%)$, wrong use of adverb $(7,8 \%)$, Wrong use of verb group $(15,7 \%)$, and errors in the use of relative clauses and relative pronouns $(5,9 \%)$.

The most common error committed by the students is errors due to lack of concord $(39,2 \%)$. It occurs because of some reasons. First, most of the students failed to compose a sentence with the correct subject-verb agreement. They tend to omit the letter " $s$ " in the verbs that belongs to the third person singular subject like she, my mother, and my mom. Besides, some students also omit an auxiliary verb before an adjective in the sentence like using 
Ramadhan et al., A Morpho-Syntactic Error...

"I angry" instead of "I am angry" and "I naughty" instead of "I am naughty" and before a noun such as "My mom hard worker". Meanwhile, such an inclusion also occurs in a sentence "we are love my mom too". Moreover, some students also failed to use correct auxiliary verb in "I don't will angry" and to change a verb into a noun/ gerund in "..to study cook.." and "...because study cook very important..". However, in the use of tense, there is no student commit an error in using simple present tense. It means that the students are fully aware of and understand the tense that must be used in writing descriptive text.

The frequent type of error in the second position committed by the students is errors in the use of prepositions $(17,6 \%)$. It occurs due to some reasons; 1$)$ the use of 'for' instead of 'of' in "sometimes I think for make happy tomy mom", 2) the use of 'for' instead of 'to'n "I always try for make happy to my mom by work something I can" and in "My mother always remain for study and pray", 3) inappropriate addition in "I always try for make happy to my mom by work something I can" and "I always pray to the god for to be the good boy", 4) omission of prepositions 'of' after the word 'because' in 'I don't will angry because mom" and 'with' after the word 'together' and in "I so sad, if she not together me". 5) the use of 'at' instead of "in the" in "at morning, my mom wake me up and ask me to pray", 6) the use of 'to' instead of 'for' in "My mother hard worker to me" and "I can't cook, but she is wake me up to study cook besides study lesson because study cook very important to the future to be her, mother".

Another frequent type of error found in the students' written products is wrong use of verb group (15,7\%). It happens due to some reasons; 1) the use of noun after subject in the sentences "She hard worker for me", "My mom education for to be good boy", "T always entertainment when my mom cry", and "My mother hard worker to me". Those nouns must be changed to be verbs works, educates, entertain, and works.2) the use of adverb after subject in the sentences "She usually lovely me and my brothers and my sisters, so we are love my mom too" and "I so sad, if she not together me". Those adverbs need to be changed to be verbs loves and does not get together. 3) Wrong spelling in "My mother always remain for study and pray". It should be reminds. 4) the use of 'to' after modal 'will' in "I will to try my mom happy". A modal must be followed by 
verb I. Thus, the sentence should be "I will try to make my mom happy".

The next type of error committed by the students is wrong use of adverb (7,8\%). The reasons for this type of error are: 1) redundant use of adverb in "Everyday morning I belp my mother because I love my mom everyday". The correct one should be "Every morning I help my mother because I love my mom everyday". Other redundancies are also found in "She is a first girl are very the best" and "She sometimes buy food every morning for my lunch." The former cannot use adverb 'very' since 'the best' means "in the highest degree". The latter does not need to use adverb 'sometimes' since it does not make any sense when it is used with the adverb 'every morning'. 2) the use of adjective 'easy' instead of adverb 'easily' in the sentence "She is not easy angry and a lovely girl".

Then, there are two types of errors with the same number of errors. Those are wrong use of conditional sentences $(5,9 \%)$ and errors in the use of relative clauses and relative pronouns $(5,9 \%)$. The wrong use of conditional sentences is caused by omission of modal 'will' that can be found in the sentences "I so sad, if she not together me", "If I do mistake, she is usually advice to wake me up to be good person", and "If I give up, she always give me support." Thus, the correct sentences should be "I will be so sad, if she does not get together with me", "If I do mistake, she will usually advise me to be a good person", and "If I give up, she will always give me support." In addition, the errors in the use of relative clauses and relative pronouns are found in the sentences "I have my parent is my father and mother" and "She is a first girl are very the best". Thus, the correct sentences should be "I have parents who are my father and mother" and "She is the first girl who is the best".

The most rare types of errors committed by the students are errors in the use of articles $(3,9 \%)$ and wrong word order $(3,9 \%)$. The errors in the use of article occur due to inappropriate use of article 'the' and ' $\boldsymbol{a}$ ' in the sentences 'I always pray to the god for to be the good boy" and "She is a first girl are very the best". Since the former is not used to refer to a specific person, it must use an article ' $\boldsymbol{a}$ ' and an article 'the' is appropriate for the latter because the word 'first' refers to ordinal number that should be preceded by an article 
Ramadhan et al., A Morpho-Syntactic Error...

'the'. Besides, there are errors of wrong word order which are caused by wrong position of adverb "sometimes" in "My mom sometimes is mad with me because I naughty" and preposition "to" in "I will to try my mom happy". Thus, they should be "my mom is sometimes mad with me because I am naughty" and "I will try to make my mom happy".

Another category of errors committed by the students can be viewed from the sources of the errors. There are five types of errors committed by the students. Those are overgeneralization $(43,13 \%)$, hypercorrection $(19,6 \%)$, faulty categorization $(11,76 \%)$, simplification $(17,64 \%)$, and transfer of rule $(7,84 \%)$. The most common error committed by the students is overgeneralization error $(43,13 \%)$.

The students tend to overgeneralize the rules of subject and verb agreement. They do not consider that the use of verb is also influenced by its subject. The examples of this error are in my mom wake me up and ask me to pray, she always give advice for me, ...she prepare all, and so forth. The students do not take into consideration the suffix -s or -es that should be used in those sentences. Besides, they also overgeneralize the use of preposition for, it can be seen in Sometimes I think for make happy to my mom, I always try for make happy to my mom by work something I can, My mother always remain for study and, and so forth. The function of that preposition is overlapping to the preposition to. Based on the sources of errors, the students should be taught more to not to overgeneralize the rules of subject-verb agreement, preposition usage, and articles usage, since they make those errors for the most.

The students also did the hypercorrections. They tend to add some unnecessary predicates in one sentence such as in I don't will angry because mom and I can't cook, but she is wake me up to study.... Besides, the students also tend to add double adverb of time such as in Everyday morning I help my mother because I love my mom every day. In term of faulty categorization, the students tend to replace the gerund with the verb for, such as in I always try for make happy... and ...my mom by work something... Besides, they also tended to replace the verb from with its noun form, such as in my mom education for to be good boy and I always entertainment when my 
mom.... Moreover, the students also tended to replace the verb with its adverb form.

In term of simplification, the students tended to omit some words in the sentences. They tend to omit the relative pronoun such as in she is a first girl (who) are very the best. Besides, they also tended to omit the to be such as in I (am) so sad, sometimes I (am) angry, and my mom (is) hard worker. Moreover, they also tended to omit the verb after the modal such as in I will to try my mom happy. Then, in term of transferring of the rule, the students tended to use Indonesian language rule in the English such as in I will to try my mom happy. However, the percentage of transferring Indonesian language into English is quite few.

In comparison with another study, these results do not correspond to that of Hariri's (2012) study as those errors (errors due to lack of concord) were not dominantly carried out by his research subjects. Although the subjects of his study and the recent study are similar in age group, his study showed that "use of prepositions" is the most frequent part of the subjects' errors. Meanwhile the minimum frequency of errors is related to errors in the use of relative clauses and relative pronouns and wrong use of verbs. This difference indicates that some factors may contribute to the aspects of each study. It is assumed that the research subjects can strongly influence the results of the two studies since the subjects in both studies come from different background of language (Indonesian and Persian).

\section{CONCLUSION}

Based on the findings and discussion we can conclude that the students need to learn more of how to use concord. Besides, they also need to stop to overgeneralize the rules in English. The overgeneralizations made by students are the overgeneralization in the rules of subject-verb agreement, the use of preposition, and the use of article. Those two kinds of errors are the most errors that are made by the students. Besides, there are also some errors that they made outside of those two. According to the morphosyntactic taxonomy, there are errors in the use of articles $(3,9 \%)$, errors in the use of prepositions $(17,6 \%)$, wrong word order $(3,9 \%)$, errors due to lack of concord $(39,2 \%)$, wrong use of 
Ramadhan et al., A Morpho-Syntactic Error...

conditional sentences $(5,9 \%)$, wrong use of adverb (7,8\%), wrong use of verb group $(15,7 \%)$, and errors in the use of relative clauses and relative pronouns $(5,9 \%)$. Besides, according to the sources of the errors, there are errors based on overgeneralization $(43,13 \%)$, hypercorrection $(19,6 \%)$, faulty categorization $(11,76 \%)$, simplification $(17,64 \%)$, and transfer of rule $(7,84 \%)$. In sum, the students and also their teacher should pay attention more to learn the way how the use of concord correctly and not to overgeneralize the rules of the subject-verb agreement, the use of preposition for, and the use of article.

\section{REFERENCES}

Amin, A. A. (2017). The frequency of morpho-syntactic errors by kurdish EFL learners. Journal of Humanities and Social Science, 22(3), 68-70.

Corder, S.P. (1967). The significance of learners' errors. Applied Linguist, (5), 161-169.

Corder, S. P. (1971). Idiosyncratic dialects and error analysis. Groos, Heidelberg, 14.

Endang, F. (2016). Applied Linguistics: Principles of Foreign Language Teaching, Learning, and Researching. Era Pustaka Utama.

Mahsa, H. (2012). Taxonomy of morpho-syntactic errors and error analysis. Research Journal of Applied Sciences, Engineering and Technology, 4(22): 4856-4860.

Keshavarz, M. H.. (2006). Error Analysis: A Practical Course for English Students and Teachers. SAMT: Tehran.

Kothari, C. R. (2004). Research Methodology: Methods \& Techniques. New Delhi: New Age International Limited Publisher.

Theo, V. (1992). Detecting and Correcting Morpho-syntactic Errors in Real Texts. Netherlands: University of Nijmegen.

Yin, R. K. (2003). Case study research: Design and methods. London: SAGE Publication, Inc.

Firas, Z. (2012). Applied error analysis of written production of English essays of tenth grade students in Ajloun schools, Jordan. International Journal of Learning \& Development, 2(2), 280-299. 